This PDF is a selection from an out-of-print volume from the National Bureau of Economic Research

Volume Title: R\&D and Productivity: The Econometric Evidence

Volume Author/Editor: Zvi Griliches

Volume Publisher: University of Chicago Press

Volume ISBN: 0-226-30886-3

Volume URL: http://www.nber.org/books/gril98-1

Publication Date: January 1998

Chapter Title: Interindustry Technology Flows and Productivity Growth: A Reexamination

Chapter Author: Zvi Griliches

Chapter URL: http://www.nber.org/chapters/c8348

Chapter pages in book: (p. 241 - 250) 


\section{0 \\ Interindustry Technology Flows and Productivity Growth: A Reexamination}

\section{1}

There is, by now, a substantial literature devoted to analyzing the effects of $R \& D$ investments by firms and industries on various measures of economic performance, especially profitability and productivity growth. Schmookler (1966) was among the first to articulate the view that improvements in performance associated with technological progress could result not only from $R \& D$ performed within an enterprise or sector, but also from R\&D performed elsewhere and "embodied" in intermediate goods purchased by the sector. He proposed a method for measuring the transmission of $\mathrm{R} \& \mathrm{D}$-generated knowledge from R\&D-performing industries to industries purchasing their products. Scherer (1981) undertook the difficult task of constructing an "interindustry technology flows" matrix along the lines suggested by Schmookler, thus providing the basis for empirical investigation of the link between $R \& D$ "embodied" in purchased producers' goods and a sector's own economic performance. Scherer's (1982a) own analysis of productivity growth among U.S. manufacturing industries provides support for the view that "imported" or "embodied" $\mathrm{R} \& \mathrm{D}$ is an important determinant of productivity growth, contributing perhaps even more than some of the R\&D performed within an industry.

The purpose of this note is to re-examine the role of interindustry technology flows in promoting productivity growth, in the light of more detailed and possibly better productivity data. Our analysis is also somewhat more general than Scherer's in the sense that we test a restriction on the equality of different R\&D-coefficients which is imposed a priori in his study. Because an explicit theoretical foundation for the hypothesis of a productivity-accelerating effect

This chapter is coauthored with Frank Lichtenberg and is reprinted from the Review of Economics and Statistics 66, no. 2 (May 1984): 324-29. Published for Harvard University by the NorthHolland Publishing Company. (C) 1984 by the President and Fellows of Harvard College. 
of imported R\&D has not, to our knowledge, been presented in the literature, we offer, in the next section, an interpretation of this effect in terms of errors in the measurement of intermediate input prices. In the third section we review Scherer's findings and present new evidence based on recently developed alternative productivity indices. A summary and conclusion follow.

\section{2}

The hypothesis that the productivity behavior of a given industry may be affected by the R\&D performance of industries which supply it with intermediate inputs follows from the assumption that there are errors in the output deflators of supplying industries - and consequently in the intermediate input deflators of using industries-errors which are generated by and correlated with suppliers' R\&D performance. By "errors" in the deflators we mean the failure of these deflators to reflect accurately changes in the user value, or marginal productivity, or quality, of the commodities whose prices they are supposed to index. As discussed in some detail in Griliches (1979, pp. 97-99) this failure may occur for at least two quite distinct reasons: (1) only a perfectly discriminating monopolist with a secure market position would be able to appropriate all of the (social) returns (or "quasi-rents") to his innovation; and (2) the U.S. Bureau of Labor Statistics (BLS), which constructs the official price indexes, generally does not adjust the indexes for "costless" quality improvements embedded in new products; instead, a new product is "linked in" at its introductory (or subsequent) price with the price index left unchanged. These considerations imply that, if a firm conducted $R \& D$ in order to build a better mousetrap (to choose a humble example), and subsequently succeeded in producing "twice as good" a mousetrap by virtue of its research efforts, the official mousetrap price index may not decline, even if the nominal price of the new mousetrap increased by less than $100 \%$, due to competition in the mousetrap industry.

To formalize this argument, we begin by postulating the existence of errors in the measurement of the growth rate of materials deflators:

$$
\dot{P} m_{j}=\dot{P} m_{j}^{*}+\varepsilon_{j}
$$

where

$P m_{j}=$ actual deflator for $j$ th intermediate input;

$P m_{j}^{*}=$ true deflator for $j$ th intermediate input;

$\varepsilon_{j}=$ measurement error, and dot superscripts indicate growth rates.

Assuming that the growth rate of the (current-dollar) value of intermediate transactions is measured without error, the accounting identity relating the value, quantity and price of intermediate input reveals a corresponding error in the growth rate of input quantity: 


$$
\begin{aligned}
M_{j} & =V m_{j} / P m_{j} \\
\dot{M}_{j} & =\dot{V} m_{j}-\dot{P} m_{j} \\
\dot{M}_{j}^{*} & =\dot{V} m_{j}-\dot{P} m_{j}^{*} \\
\dot{M}_{j}^{*}-\dot{M}_{j} & =\dot{P} m_{j}-\dot{P} m_{j}^{*}=\varepsilon_{j}
\end{aligned}
$$

where

$M_{j}=$ measured quantity of $j$ th intermediate input;

$M_{j}^{*}=$ true quantity of $j$ th intermediate input;

$V m_{j}=$ actual value of $j$ th intermediate input.

Thus errors in the materials deflator result in errors in the measured rate of growth of total factor productivity of using industry $i\left(T \dot{F} P_{i}\right)$ :

$$
\begin{aligned}
T \dot{F} P_{i} & =\dot{Q}_{i}-\sum_{k} S_{i k} \dot{X}_{i k}-\sum_{j} S_{i j}\left(\dot{M}_{i j}^{*}-\varepsilon_{j}\right) \\
T \dot{F} P_{i}^{*} & =\dot{Q}_{i}-\sum_{k} S_{i k} \dot{X}_{i k}-\sum_{j} S_{i j} \dot{M}_{i j}^{*} \\
T \dot{F} P_{i}-T \dot{F} P_{i}^{*} & =\sum_{j} S_{i j} \varepsilon_{j} \\
T \dot{F} P_{j} & =T \dot{F} P_{j}^{*}+\sum_{j} S_{i j} \varepsilon_{j}
\end{aligned}
$$

where

$\dot{Q}_{i}=$ output growth rate of industry $i$;

$\dot{X}_{i k}=$ growth rate of $k$ th non-materials input to industry $i$;

$S_{i k}=$ share of $i$ th non-materials input in total cost of production of industry $i$;

$S_{i j}=$ share of $j$ th materials input in total cost of production of industry $i$.

Measured TFP growth of industry $i$ thus deviates from its actual TFP growth by the weighted sum of errors in the various materials deflators, using respective cost shares as weights.

To this definitional relationship between measured productivity growth and errors in the deflators we add the assumption that the extent of mismeasurement of the growth in the $j$ th intermediate-input deflator-in other words, in the output deflator of industry $j$-depends on the extent of product-oriented $R \& D$ activity in the supplying industry. Since process-oriented $R \& D$ does not alter the characteristics of products sold in interindustry transactions, it should not contribute to errors in the measurement of deflators corresponding to these transactions.

More specifically, we assume that the extent of measurement error in the 
rate of growth of the $j$ th materials deflator is proportional to the $R \& D$ intensity (R\&D expenditure per unit of output) of supplying industry $j .^{1}$ Then

$$
\varepsilon_{j}=\gamma \frac{R D_{j}}{V q_{j}},
$$

where

$R D_{j}=$ product-oriented $\mathrm{R} \& \mathrm{D}$ expenditures by industry $j ;$

$V q_{j}=$ value of output produced by industry $j$.

Hence,

$$
\begin{aligned}
T \dot{F} P_{i} & =T \dot{F} P_{i}^{*}+\sum_{j} S_{i j} \gamma \frac{R D_{j}}{V q_{j}} \\
& =T \dot{F} P_{i}^{*}+\gamma \sum_{j} \frac{V q_{j i}}{V q_{i}} \cdot \frac{R D_{j}}{V q_{j}} \\
& =T \dot{F} P_{i}^{*}+\gamma \frac{1}{V q_{i}} \sum_{j} \frac{V q_{j i}}{V q_{j}} R D_{j} .
\end{aligned}
$$

$V q_{j i} / V q_{j}$ is the share of the supplying industry $j$ 's output sold to using industry $i$. If the benefits of $R \& D$ enjoyed by one consumer (purchasing industry) are not available to other consumers, and the benefits of suppliers' $R \& D$ are distributed among purchasers in proportion to suppliers' sales to them, then $\left(V q_{j i} / V q_{j}\right) \cdot R D_{j}$ is an index of the benefits of industry $j$ 's R\&D enjoyed by industry $i$. Summing over all supplying industries and dividing by the output of the $i$ th industry yields a measure of the "embodied-R\&D intensity" of the using industry, analogous to the "own" R\&D-intensity variable often specified in previous investigations. The "true" own rate of industry $i$ 's TFP growth, $T \dot{F} P_{i}^{*}$, is, of course, unobservable but provided that this variable is uncorrelated with the R\&D intensity embodied in its purchased inputs, estimation of (1) excluding $T \dot{F} P_{i}^{*}$ will yield an unbiased estimate of $\gamma^{2}$

\section{3}

The index of the quantity of R\&D embodied in industry $i$ 's purchases of intermediate inputs in (1) is rather crude, in the sense that industry $j$ 's $R \& D$ activity is assumed to be homogeneous with respect to the interindustry distri-

1. We recognize that this is merely one-albeit a convenient one-of a class of "reasonable" possible assumptions about the effects of $R \& D$ on quality-adjusted output prices. For example, the measurement error might be postulated to depend on the level of R\&D rather than R\&D-intensity.

2. A similar argument involving the direct contribution of process R\&D to TFP growth in industry $i$, and its exclusion from the list of conventional inputs in the construction of the usual TFP measures, leads to a relationship between measured TFP and own R\&D intensity. (See Griliches, 1979.) 
bution of embodied benefits. In reality, some of industry $j$ 's R\&D investments may benefit industry $i$ more than others, and if it were possible to classify industry $j$ 's R\&D expenditure by the extent of benefits (possibly zero) received by industry $i$, for all $i$ and $j$, we could obtain a more precise measure of the technology flows embodied in interindustry transactions. Scherer attempts to do just this, using data on corporate patents, each of which was classified by "industry (or industries) of use" as well as by "industry of origin." The details of the rather complex procedure for developing estimates of embodied $R \& D$, by origin and destination industry, are reported in Scherer (1981). It is these figures, aggregated over all supplying industries, that are used in order to estimate the contribution of embodied R\&D to productivity growth; the index specified in (1) should be regarded as merely a rough approximation for heuristic purposes.

The productivity growth-rate equations estimated by Scherer on crosssectional industry data included a measure of the industry's own or performed $R \& D$ intensity as well as of its embodied-R\&D intensity. Scherer distinguished between product- and process-oriented $R \& D$ performed within an industry, and hypothesized that the intensity both of process $R \& D$ performed within the industry and of $R \& D$ embodied in purchased inputs should have stronger effects on measured productivity growth in the industry than the intensity of its "own" product R\&D. He reports estimates of equations in which "own" process $R \& D$ and embodied $R \& D$ are added together to form a "used" $R \& D$ variable, and own product $R \& D$ is included as a separate regressor. Distinct versions of the model were estimated on productivity data derived from two different sources, both within the U.S. Bureau of Labor Statistics (BLS): the Office of Economic Growth's input-output industries' data (BLSIO) in which output is measured primarily as deflated shipments adjusted for inventory change, and physical-quantity-based output data published by the Industry Productivity Division (BLSPQ). In order to investigate whether the link between $R \& D$ intensity and productivity growth has exhibited structural change -in particular, secular weakening - the model was estimated separately for two definitions of the dependent variable, corresponding to two spans of years over which the growth rate of TFP was measured: 1964-69 and 1973$78 .{ }^{3}$ Because the $R \& D$ data were available only for a single year, 1974 , the same R\&D-intensity measures are included in the regressions for both periods.

Scherer's estimates of the coefficients of the R\&D-intensity variables and their associated $t$-statistics are reproduced in the first and third lines of table 10.1. The dependent variable in these regressions is the growth rate of labor productivity (output per man-hour); a measure of the growth rate of the capitallabor ratio was also included in these equations, but the corresponding coefficient estimates are not reproduced here. In the regressions in the first line, $R \& D$ intensity is defined as (own-product or user) $R \& D$ investment per unit

3. These spans of years were chosen because both of the beginning and end years were postulated to represent business cycle peaks. 


\begin{tabular}{|c|c|c|c|c|c|c|c|}
\hline \multirow[b]{3}{*}{ Investigator } & \multirow{3}{*}{$\begin{array}{c}\text { Source of } \\
\text { Productivity } \\
\text { Data }\end{array}$} & \multirow{3}{*}{$\begin{array}{c}\text { Denominator of } \\
\text { R\&D-Intensity } \\
\text { Variables }\end{array}$} & \multirow{3}{*}{$\begin{array}{l}\text { Number of } \\
\text { Observations } \\
\text { (industries) }\end{array}$} & \multicolumn{4}{|c|}{$\begin{array}{l}\text { Coefficients ( } l \text {-statistics) on } \\
\text { R\&D-Intensity Variables }\end{array}$} \\
\hline & & & & \multicolumn{2}{|c|}{$1964-1969$} & \multicolumn{2}{|c|}{$1973-1978$} \\
\hline & & & & $P R O D$ & USER & $P R O D$ & USER \\
\hline Scherer & BLSIO & Gross Output & 87 & $\begin{array}{r}0.133 \\
(1.05)\end{array}$ & $\begin{array}{r}0.643 \\
(1.84)\end{array}$ & $\begin{array}{r}0.289 \\
(2.01)\end{array}$ & $\begin{array}{r}0.742 \\
(1.89)\end{array}$ \\
\hline G-L & $\begin{array}{l}\text { Revised } \\
\text { Census et al. }\end{array}$ & Gross Output & 193 & $\begin{array}{r}0.146 \\
(1.78)\end{array}$ & $\begin{array}{r}0.736 \\
(3.97)\end{array}$ & $\begin{array}{r}0.282 \\
(2.58)\end{array}$ & $\begin{array}{r}0.504 \\
(2.03)\end{array}$ \\
\hline Scherer & BLSPQ & Value Added & 37 & $\begin{array}{r}0.051 \\
(0.34)\end{array}$ & $\begin{array}{r}0.401 \\
(1.42)\end{array}$ & $\begin{array}{r}0.089 \\
(0.46)\end{array}$ & $\begin{array}{r}0.711 \\
(2.03)\end{array}$ \\
\hline G-L & $\begin{array}{l}\text { Revised } \\
\text { Census et al. }\end{array}$ & Value Added & 193 & $\begin{array}{r}0.083 \\
(1.84)\end{array}$ & $\begin{array}{r}0.404 \\
(3.98)\end{array}$ & $\begin{array}{r}0.160 \\
(2.67)\end{array}$ & $\begin{array}{r}0.255 \\
(1.88)\end{array}$ \\
\hline
\end{tabular}


of gross 1974 output; in the regressions in line 3 the denominator of the R\&Dintensity variable is 1974 value added (gross output minus purchases of intermediate materials). In the second and fourth lines we present new, comparable estimates based on productivity indices derived from a more disaggregated and presumably superior data set, the revised Census-Penn-SRI 4-digit manufacturing data file. This data set, described in some detail in an appendix to Griliches and Lichtenberg (1982), consists essentially of time-series on gross output and four inputs - capital, labor, energy, and materials - in current and constant (1972) dollars, for the period 1958-1978. Productivity indices based on these data, unlike those used by Scherer, take account of the growth in energy and materials inputs, which is likely to be of particular importance in the 1970s due to the sharp increases then in the relative prices of these inputs. The BLSIO data appear to suffer from an additional defect, the "misalignment" of the output and labor input series, ${ }^{4}$ which introduces unknown errors into the labor productivity indices. The discrepancies among data sets in the (unweighted) sample mean productivity growth rates, presented below, and in the implied deceleration of productivity result, in part, from these conceptual differences:

$1964-69$

Labor Productivity

BLSIO

BLSPQ

TFP

Revised Census
2.81

2.99

0.96
$1973-78$

2.03

2.54

$-1.16$

Despite the differences in level of industry aggregation and in the sources and concept underlying the productivity indices, our new estimates in some respects closely replicate Scherer's earlier results. In all eight regressions, the coefficient on USER exceeds that on $P R O D$, by a factor ranging from about $1 \frac{1}{2}$ to 8 , although the difference in the two coefficients generally appears to be statistically insignificant. On the other hand, while the coefficient on $P R O D$ is insignificantly different from zero in 3 of the 4 reported Scherer equations, it is significant at the $10 \%$ level in all of the new regressions. Also, whereas Scherer's results indicate an increase in both the size and significance of the coefficient on USER between the first and second periods, our estimates point to a secular decline in the effect of "user" $R \& D$ on productivity growth.

A hypothesis maintained by the model, estimates of variants of which are presented in table 10.1 , is that the coefficient on $R \& D$ embodied in purchased inputs is equal to the coefficient on process $R \& D$ performed within the industry. Our data permit us to test both this hypothesis and that of the equality of the coefficients on own-product and own-process $R \& D$.

4. Industry output is defined as the total output of establishments classified in (i.e., whose primary product defines) the industry, plus the secondary production by establishments classified in other industries of products which are primary to this industry. Industry employment, on the other hand, is defined simply as persons employed in establishments classified in the industry. 
Although we have annual data on industry productivity, allowing us to construct multiple (e.g., year-to-year) productivity growth observations for each industry, observations on the right-hand-side variables of our model are available only for a single year. One could estimate a pooled annual equation by imputing an industry's single (1974) values of the right-hand-side variables to that industry's productivity data for all years, but this procedure would produce a misleading impression of precision. In the absence of more complete data, we are forced to analyze the relationships between an industry's average rate of productivity growth and its (own- and embodied-) R\&D intensity as of 1974 which we take as a good proxy of its average $R \& D$ intensity during the 1970 s. (This is not too bad an assumption since such numbers change only very slowly over time. See the evidence presented in Griliches and Lichtenberg (1982).) Thus, we ran a set of cross-sectional regressions in which the dependent variable was defined as the growth rate in the average level of TFP between adjacent five-year periods. For example, the average level of TFP (indexed to 100.0 in 1972) during each of the five-year periods $1969-73$ and 1974-78 was calculated, and then the five-year compound growth rate between these averages was computed. Differences between period averages, rather than differences between period endpoints, were used to reduce the transitory and cyclical components in measured TFP, but the actual results are not very sensitive to this treatment of the dependent variable.

A summary of regressions of this definition of the TFP growth rate, by subperiod, on selected R\&D-intensity variables, is presented in table 10.2. Three models were estimated for each subperiod. In the first, or unrestricted, model, three "types" of R\&D— "own" process R\&D (i.e., process $R \& D$ performed by the using industry), "own" product $R \& D$, and product $R \& D$ embodied in inputs purchased from other industries-are included as separate regressors in the equation. In the other two models, different pairs of the $R \& D$ variables are added together, in order to test the linear restriction of equality of the respective coefficients. Estimation of the second model provides a test of the hypothesis that the two types of "own" R\&D have similar effects on productivity; similarity of the effects of "own" process and imported product R\&D is considered in the third equation.

These results are consistent with the hypothesis that product-oriented $R \& D$ performed within an industry has less of an effect on that industry's measured TFP growth rate than either process $R \& D$ performed or $R \& D$ embodied in purchased inputs. The coefficient on own-product $R \& D$ is the smallest in both the unrestricted and restricted models for all three periods. For the first two periods we can reject the hypothesis at the $10 \%$ level that the two types of $\mathrm{R} \& \mathrm{D}$ performed within the industry have equal coefficients. In contrast, the hypothesis that own-process and imported $R \& D$ have equal coefficients cannot be rejected in any period, although this finding appears to be an artifact of the large standard errors associated with the imported-R $\& D$ coefficients. In this, it is similar to the results reported by Scherer (1982a, p. 633), except that we 


\begin{tabular}{|c|c|c|c|c|c|c|c|c|c|}
\hline Table 10.2 & \multicolumn{9}{|c|}{$\begin{array}{l}\text { Summary of Regressions of Total Factor Productivity Growth Rate, by Subperiod, on Selected R\&D-Intensity Variables Derived } \\
\text { from Scherer "Interindustry Technology Flows" Data Base }\end{array}$} \\
\hline & & & & $\begin{array}{c}\text { "Own" } \\
\text { Process }+\end{array}$ & $\begin{array}{c}\text { "Own" } \\
\text { Process }+\end{array}$ & & & $\begin{array}{l}F \text {-ratio (associat } \\
\text { on Test of Equa }\end{array}$ & $\begin{array}{l}\text { obability value) } \\
\text { of Coefficients }\end{array}$ \\
\hline $\begin{array}{c}\text { Dependent } \\
\text { Variable }\end{array}$ & $\begin{array}{c}\text { Process } \\
\text { R\&D }\end{array}$ & $\begin{array}{l}\text { Product } \\
\text { R\&D }\end{array}$ & $\begin{array}{l}\text { Product } \\
\text { R\&D }\end{array}$ & $\begin{array}{l}\text { Product } \\
\text { R\&D }\end{array}$ & $\begin{array}{c}\text { Product } \\
\text { R\&D }\end{array}$ & Constant & $R^{2}$ & Process/Product & Process/Import \\
\hline $\begin{array}{c}\text { TFP Growth, } \\
1959-63 \text { to } \\
1964-68\end{array}$ & $\begin{array}{r}0.762 \\
(2.82)\end{array}$ & $\begin{array}{r}0.211 \\
(2.45)\end{array}$ & $\begin{array}{r}0.289 \\
(0.60)\end{array}$ & & & $\begin{array}{r}0.093 \\
(4.51)\end{array}$ & .1151 & & \\
\hline & & & $\begin{array}{r}0.512 \\
(1.09)\end{array}$ & $\begin{array}{r}0.286 \\
(3.73)\end{array}$ & & $\begin{array}{r}0.093 \\
(4.45)\end{array}$ & .0993 & $\begin{array}{c}3.37 \\
(0.07)\end{array}$ & \\
\hline & & $\begin{array}{c}0.206 \\
(2.40)\end{array}$ & & & $\begin{array}{r}0.621 \\
(3.19)\end{array}$ & $\begin{array}{r}0.089 \\
(4.51)\end{array}$ & .1124 & & $\begin{array}{c}0.56 \\
(0.15)\end{array}$ \\
\hline $\begin{array}{l}\text { TFP Growth, } \\
1964-68 \text { to } \\
1969-73\end{array}$ & $\begin{array}{r}0.578 \\
(2.84)\end{array}$ & $\begin{array}{r}0.040 \\
(0.61)\end{array}$ & $\begin{array}{r}0.687 \\
(1.89)\end{array}$ & & & $\begin{array}{r}0.005 \\
(0.34)\end{array}$ & .1050 & & \\
\hline & & & $\begin{array}{c}0.904 \\
(2.54)\end{array}$ & $\begin{array}{r}0.112 \\
(1.94)\end{array}$ & & $\begin{array}{r}0.005 \\
(0.29)\end{array}$ & .0780 & $\begin{array}{c}5.69 \\
(0.02)\end{array}$ & \\
\hline & & $\begin{array}{r}0.041 \\
(0.63)\end{array}$ & & & $\begin{array}{r}0.610 \\
(4.17)\end{array}$ & $\begin{array}{r}0.006 \\
(0.43)\end{array}$ & .1047 & & $\begin{array}{c}0.05 \\
(0.82)\end{array}$ \\
\hline $\begin{array}{c}\text { TFP Growth, } \\
1969-73 \text { to } \\
1974-78\end{array}$ & $\begin{array}{r}0.384 \\
(1.37)\end{array}$ & $\begin{array}{c}0.299 \\
(3.35)\end{array}$ & $\begin{array}{r}0.465 \\
(0.93)\end{array}$ & & & $\begin{array}{c}-0.100 \\
(4.69)\end{array}$ & .1078 & & \\
\hline & & & $\begin{array}{r}0.499 \\
(1.04)\end{array}$ & $\begin{array}{r}0.310 \\
(3.95)\end{array}$ & & $\begin{array}{c}-0.100 \\
(4.71)\end{array}$ & .1075 & $\begin{array}{c}0.07 \\
(0.78)\end{array}$ & \\
\hline & & $\begin{array}{r}0.299 \\
(3.38)\end{array}$ & & & $\begin{array}{r}0.408 \\
(2.03)\end{array}$ & $\begin{array}{c}-0.099 \\
(4.91)\end{array}$ & .1078 & & $\begin{array}{c}0.02 \\
(0.90)\end{array}$ \\
\hline
\end{tabular}

Note: $N=193$. 
get statistically significant estimates for the coefficients of own-process R\&D. Indeed, the significance of the composite USER R\&D variable seems to be due primarily to the own-process component rather than to the embodied component.

\section{4}

The findings of our re-examination of the relationship between R\&D embodied in purchased inputs and industrial productivity, while broadly consistent with Scherer's results, have somewhat different implications for the nature of this relationship. Both investigations yielded uniformly larger estimates of the coefficient of USER R\&D than of the coefficient of own-product R\&D. Scherer found also that the latter coefficients were generally insignificant and that the USER R\&D coefficient was larger in the second than in the first period. In contrast, we find own-product $R \& D$ to be a generally significant determinant of measured TFP growth, and our evidence suggests a declining efficacy of USER R\&D. Moreover, the explanatory power of the USER R\&D variable appears to derive primarily from the own-process $R \& D$ component rather than the embodied component, whose influence on TFP is weak and unstable over time. ${ }^{5}$

\section{References}

Griliches, Zvi, "Issues in Assessing the Contribution of R\&D to Productivity Growth," The Bell Journal of Economics 10 (Spring 1979), 92-116. [Reprinted as chap. 2 in this volume.]

Griliches, Zvi, and Frank Lichtenberg, "R\&D and Productivity Growth at the Industry Level: Is There Still a Relationship?" (1984). In Zvi Griliches (ed.), $R \& D$, Patents, and Productivity (Chicago: University of Chicago Press for NBER). [Reprinted as chap. 9 in this volume.]

Scherer, F. M., "Using Linked Patent and R\&D Data to Measure Inter-industry Technology Flows" (1984). In Zvi Griliches (ed.), $R \& D$, Patents, and Productivity (Chicago: University of Chicago Press for NBER).

— , "Inter-industry Technology Flows and Productivity Growth," Review of Economics and Statistics 64 (Nov. 1982a), 627-634.

- "Demand-Pull and Technological Invention: Schmookler Revisited," Journal of Industrial Economics 30 (3) (1982b), 225-238.

Schmookler, Jacob, Invention and Economic Growth (Cambridge: Harvard University Press, 1966).

5. This finding may reflect both the fact that, relatively speaking, manufacturing industries do not "import" much R\&D (though they "export" a lot to non-manufacturing industries) and that at the more disaggregated levels used by us Scherer's estimates are based on smaller samples and may be subject to more significant errors in variables problems. On the first point, see Scherer (1982b, p. 233). 